\title{
Chromosomal assignment of genes controlling salt-soluble proteins (albumins and globulins) in wheat and related species
}

\author{
P. Fra-Mon, G. Salcedo, C. Aragoncillo and F. García-Olmedo \\ Departamento de Bioquímica, E.T.S. Ingenieros Agrónomos-UPM, Madrid-3, Spain
}

\begin{abstract}
Summary. Salt-soluble proteins from the endosperms of wheat, barley, and rye have been separated by nonequilibrium electrofocusing $x$ electrophoresis. Genes encoding 14 of the 25 components observed in wheat have been unambiguously assigned to 10 different chromosomes (1B, 3B, 3D, 4A, 4D, 5B, 6B, 6D, 7B, 7D) by analysis of the compensated nulli-tetrasomic series. Five more wheat proteins seem to be controlled by group 2 chromosomes. Analysis of wheat-barley and wheat-rye addition lines has led to the location of genes for 6 out of 20 barley proteins in 4 different chromosomes $(1 \mathrm{H}, 3 \mathrm{H}, 4 \mathrm{H}, 6 \mathrm{H} ; 1 \mathrm{H}$ is homoeologous to group 7 chromosomes of wheat) and of genes for 5 out of 20 rye proteins in two different chromosomes $(2 \mathrm{R}, 4 \mathrm{R})$. The relationship between the proteins reported here and previously characterized ones is discussed.
\end{abstract}

Key words: Chromosomal location - Genetic control Salt soluble proteins - Wheat - Barley - Rye

\section{Introduction}

The cereal endosperm is one of the main sources of dietary protein for man and domestic animals. The nutritional value and certain technological properties of the cereal grains largely depend on the protein content and composition of this tissue. Numerous studies have been carried out on the biochemistry and genetics of a wide variety of endosperm protein components in the different cereal species. Most of these studies have dealt with the prolamins, storage proteins that normally represent more than half of the kernel protein and are deficient in certain essential amino acids, especially lysine. The soluble proteins, albumins and globulins, which may represent up to one fourth of the kernel protein and close to one half of the total lysine, have received less attention, in spite of their obvious nutritional relevance. In the case of wheat, barley, and rye, the genetic control of different protein components has been extensively studied using the diverse spectrum of aneuploid strains originally obtained by Sears $(1954,1966)$ and further extended in many laboratories around the world (Riley and Chapman 1958; Morris et al. 1966; Islam et al. 1975; and others). Although in some of these studies, the genetic control of specific groups of albumins and globulins has been investigated (for a review, see Garcia-Olmedo et al. 1982), no systematic study of the chromosomal locations of genes encoding these proteins has been carried out using high-resolution two-dimensional methods. We report here such a study for albumins and globulins from wheat, barley, and rye.

\section{Materials and methods}

\section{Biological materials}

The complete series of compensated nulli-tetrasomics from Triticum aestivum cv. 'Chinese Spring' (except those nullisomic for chromosomes $2 \mathrm{~A}$ and $4 \mathrm{~A}$ ) and ditelosomic $4 \mathrm{~A} \alpha$ were the gift of $E$. R. Sears from the University of Missouri (Sears 1954, 1966). Disomic addition lines of chromosomes 1 , 2, 3, 4, 6 and 7 from Hordeum vulgare cv. 'Betzes' in a $T$. aestivum cv. 'Chinese Spring' background (Islam et al. 1978) were donated by Dr. K W. Shepherd (Adelaide, Australia). The complete set of disomic addition lines, carrying chromosomes of Secale cereale cv. 'Imperial' in a background of $T$. aestivum cv. 'Chinese Spring' were obtained from Dr. E. R. Sears.

\section{Extraction and fractionation of proteins}

Individual kemels $(40-50 \mathrm{mg})$ were placed between two metal plates and crushed with a hammer. Lipids were extracted in a 
a
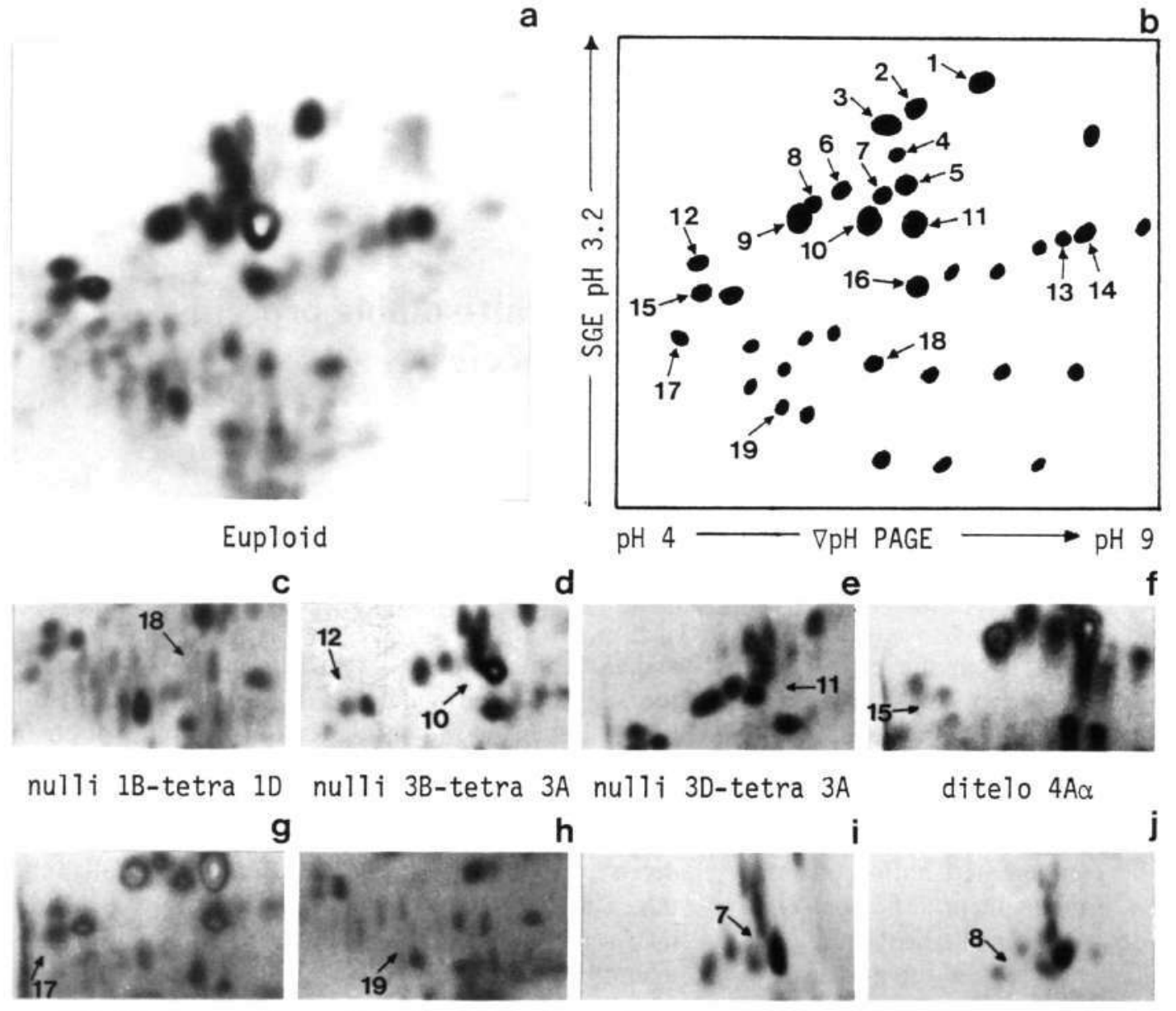

nulli 4D-tetra 4B
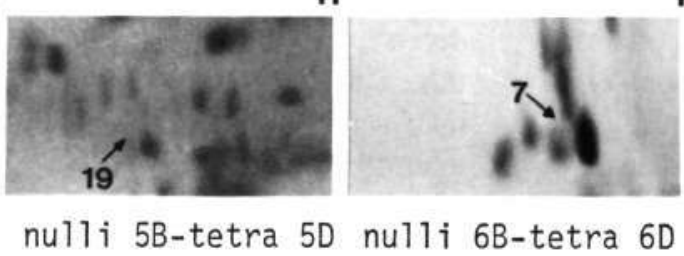

nulli $6 \mathrm{D}$-tetra $6 \mathrm{~A}$
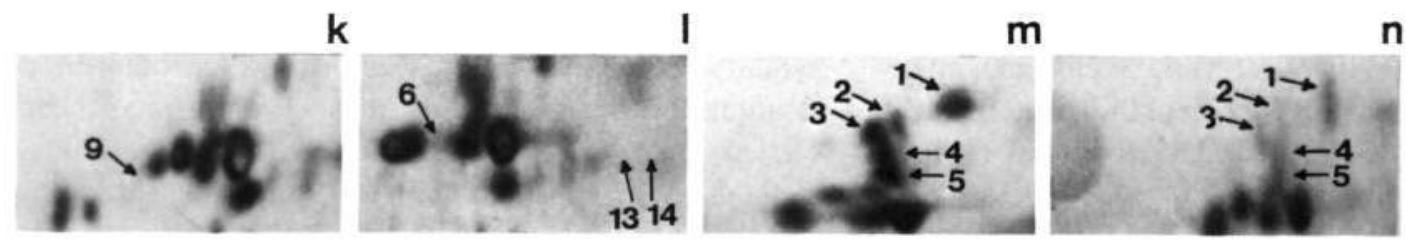

nulli 7B-tetra 7D nulli 7D-tetra 7B nulli 2B-tetra $2 \mathrm{~A}$ nulli 2B-tetra 2D

Fig. 1a-n. Aneuploid analysis of albumins and globulins of wheat. a Fractionation of combined non-equilibrium electrofocusing ( $1^{\text {st }}$ dimension) $\times$ electrophoresis ( $2^{\text {nd }}$ dimension) of salt-extracted proteins from euploid T. aestivum cv. 'Chinese Spring'. b Schematic representation of the two-dimensional protein map shown in Fig. 1 a. Components alluded to in the text have been numbered. $\mathbf{c}-\mathbf{n}$ Pertinent zones of the two-dimensional maps corresponding to the indicated aneuploids. Arrows point to the positions of the missing proteins, which in each case are identified by their corresponding numbers

small tube with 10 volumes of petroleum ether (bp $40-70^{\circ} \mathrm{C}$ ) at room temperature, and the residual flours were air-dried. Albumins and globulins were extracted from the flours with $0.5 \mathrm{M} \mathrm{NaCl}$ at $4{ }^{\circ} \mathrm{C}(2 \times 10 \mathrm{v} / \mathrm{w} ; 1 \mathrm{~h})$. After centrifugation of the extraction mixtures at $6,000 \times \mathrm{g}$ for $15 \mathrm{~min}$, proteins were precipitated from the supernatants with trichloroacetic acid $(12.5 \%$, final concentration). The precipitates were washed with $400 \mu \mathrm{l}$ of acetone, air-dried, and stored at $-20^{\circ} \mathrm{C}$ until used. The dried samples were dissolved in $50 \mu \mathrm{l}$ of $9 \mathrm{M}$ urea and fractionated by two-dimensional electrophoresis: first dimension, non-equilibrium electrofocusing on preformed $\mathrm{pH}$ gradients ( $\mathrm{pH} 4-9 ; 5 \%$ polyacrylamide; $2 \times 140 \mathrm{~mm}$ column; $\left.67 \mathrm{~V} \mathrm{~cm}^{-1}, 2-3 \mathrm{~h}\right)$; second dimension, starch-gel electro- phoresis $(0.1 \mathrm{M}$ aluminium lactate buffer, $\mathrm{pH} 3.2,3 \mathrm{M}$ urea; $1 \mathrm{~mm} \times 18 \mathrm{~cm} \times 28 \mathrm{~cm}$ slabs; $20 \mathrm{~V} \mathrm{~cm}^{-1}, 4 \mathrm{~h}$ ). The $\mathrm{pH}$ gradients (ampholines $\mathrm{pH} 4-9$; buffers $0.2 \% \mathrm{H}_{2} \mathrm{SO}_{4}$ and $0.4 \%$ ethanolamine) were prefocused at $0.5 \mathrm{~mA}$ per tube until $470 \mathrm{~V}$ were reached $(\sim 40 \mathrm{~min})$. Gels were stained with $0.05 \%$ nigrosine in methanol-water-acetic acid $(5: 5: 1$, by vol) for $16 \mathrm{~h}$.

\section{Results}

The two-dimensional fractionation of the salt extract from euploid 'Chinese Spring' wheat is shown in Fig. 1a. Preliminary experiments were carried out, at dif- 


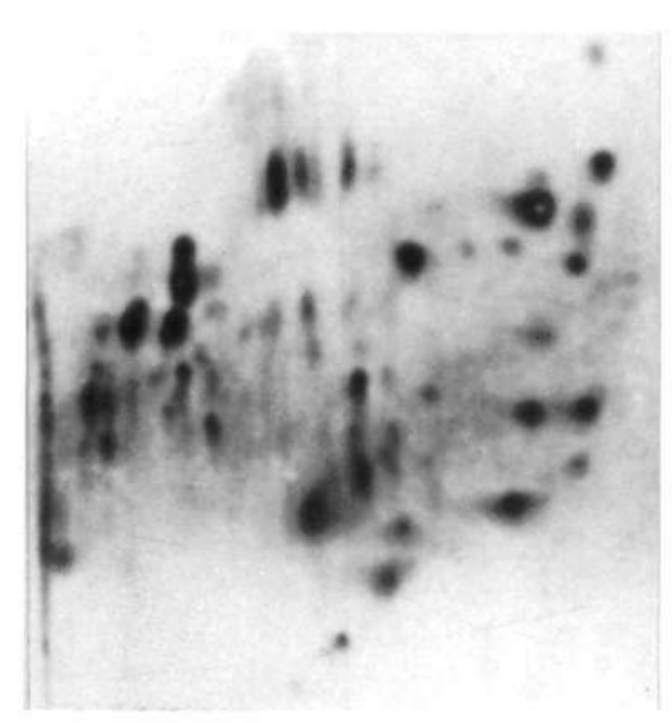

Barley cv. Betzes

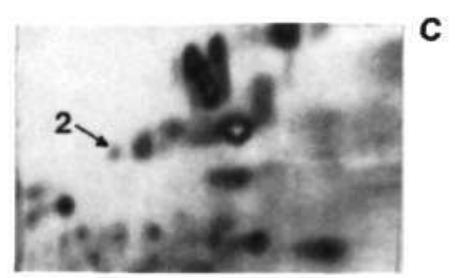

Addition line $1 \mathrm{H}$

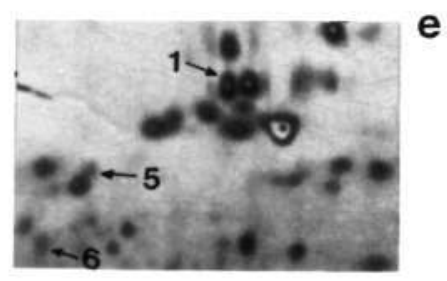

Addition line $4 \mathrm{H}$
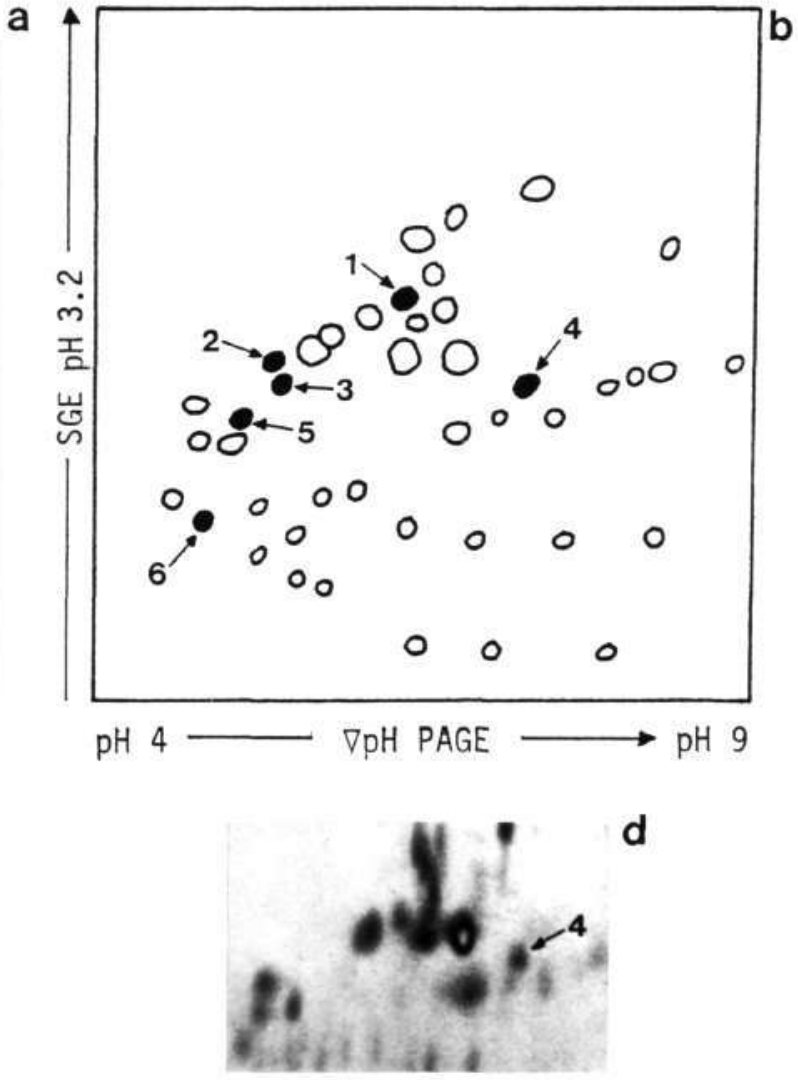

Addition line $3 \mathrm{H}$

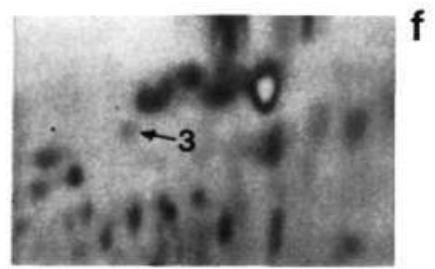

Addition line $6 \mathrm{H}$

Fig. 2a-f. Aneuploid analysis of albumins and globulins of barley. a Fractionation as in Fig. 1 of salt-extracted proteins from H. vulgare cv. 'Betzes'. b Schematic representation of the barley proteins (black spots) that can be unequivocally identified in the background of wheat proteins (open spots corresponding to those represented in Fig. Ib). $\mathbf{c}-\mathbf{f}$ Pertinent zones of the twodimensional maps corresponding to the indicated 'Chinese Spring'/Betzes' wheat/barley addition lines. Arrows and numbers indicate the additional proteins appearing in each of the addition lines shown

ferent times of non-equilibrium electrofocusing in the first dimension, to ascertain that all major components of this protein fraction (albumins and globulins) were included in the map, and the final conditions were chosen so that optimum resolution was obtained. No precipitate was observed in the sample solution during electrofocusing. About 25 main components were reproducibly observed by this procedure. No differences were observed for the main components between hand dissected endosperms and crushed whole kernels. The chromosomal assignment of genes encoding these pro- teins has been carried out by the two-dimensional analysis of compensated nulli-tetrasomic stocks and of ditelosomic $4 \mathrm{~A} \alpha$. Proteins for which information was obtained in the analysis have been numbered in the schematic representation of Fig. $1 \mathrm{~b}$. Genes encoding 13 of the main proteins (components 6-15, 17-19) were unequivocally assigned to ten different chromosomes (Table 1) on the basis of the absence of each protein in all strains lacking a particular chromosome. Although the expected dosage effects were observed in most cases, no attempt was made at densitometric 


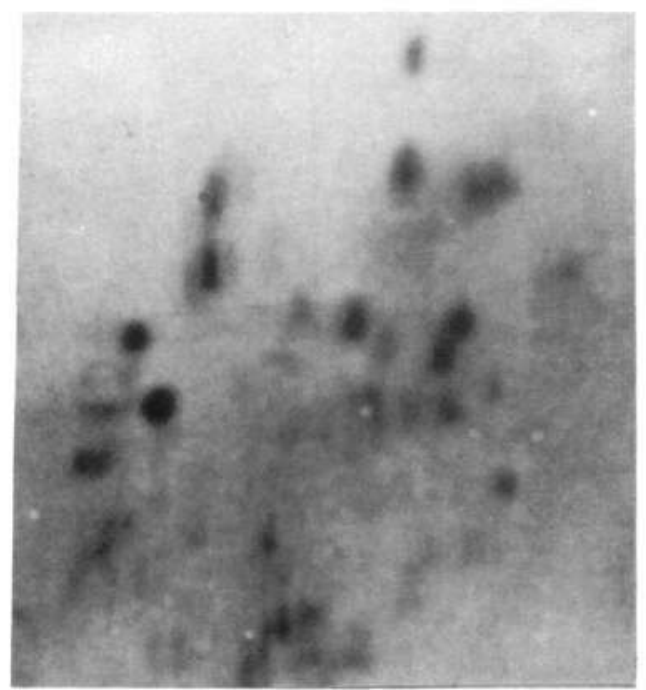

Rye cv. Imperial
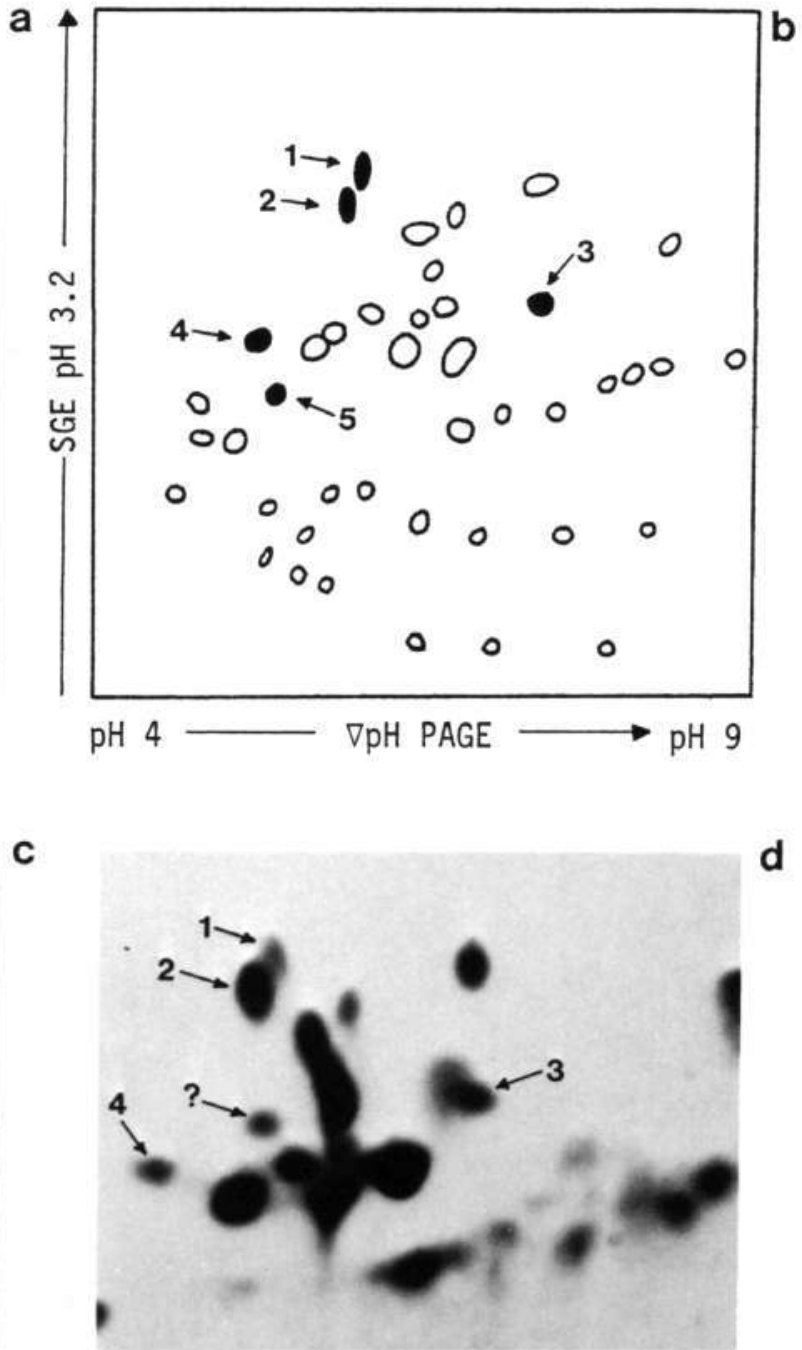

Addition line $2 R$

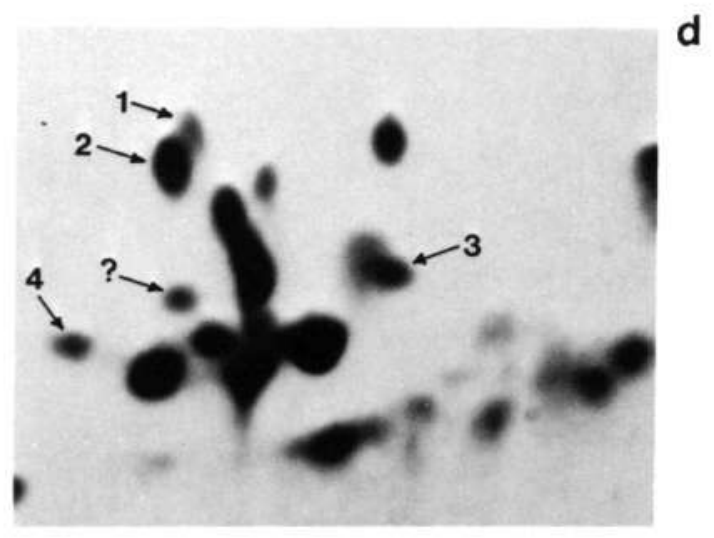

Addition line $4 R$

Fig. 3a-d. Aneuploid analysis of albumins and globulins of rye. a Fractionation as in Fig. 1 of salt-extracted proteins from $S$. cereale cv. Imperial. b Schematic representation of the rye proteins (black spots) that can be unequivocally identified in the background of wheat proteins (open spots corresponding to those represented in Fig. $1 \mathrm{~b}$ ). c-d Pertinent zones of the twodimensional maps corresponding to the indicated 'Chinese Spring'/'Imperial' wheat/rye addition lines. Arrows and numbers indicate the additional proteins appearing in each of the addition lines shown. The arrow identified with a question mark in Fig. $3 \mathrm{~d}$ points to a component that is not detected in either wheat or rye

quantitation of the spots. Relevant parts of the twodimensional maps showing the absence of the different proteins in appropriate aneuploid strains are presented in Fig. $1 \mathrm{c}-1$. Component 16 corresponds to the previously studied protein $\mathrm{CM} 3$, which was found to be encoded by at least two genes, located in chromosome $4 \mathrm{~A}$ and in an unknown chromosome of the $\mathrm{D}$ genome (Rodriguez-Loperena et al. 1975; Aragoncillo et al. 1975). Five additional proteins (components 1-5) were found at very low levels in nulli $2 \mathrm{~B}$-tetra $2 \mathrm{D}$ and at euploid levels in nulli 2 B-tetra 2 A (Fig. $1 \mathrm{~m}-\mathrm{n}$ ).

The separation of barley albumins and globulins by two-dimensional electrophoresis is shown in Fig. 2a.
About 20 main components were detected. Considerable overlap between barley and wheat components was observed when a mixture of the salt extracts from the two species was subjected to joint electrophoresis. Fig. $2 \mathrm{~b}$ is a diagram in which the barley proteins not overshadowed by wheat ones, and whose genes we were able to assign, are numbered and shown as black spots. Genes for these proteins were assigned to four different chromosomes by analysis of the six available wheat-barley addition lines (Fig. 2c-f; Table 1; addition 5 not available). It is to be noted that, in the disomic addition of chromosome $4 \mathrm{H}$ of barley (Fig. $2 \mathrm{e})$, the expression of the barley genes corresponding 
Table 1. Chromosomal assignment of genes encoding saltsoluble proteins in wheat and related species

\begin{tabular}{|c|c|c|c|c|c|c|c|c|c|}
\hline \multirow[t]{2}{*}{ Extractant } & \multirow[t]{2}{*}{ Genomes $^{*}$} & \multicolumn{7}{|c|}{$\begin{array}{l}\text { No. of components } \\
\text { encoded by chromo- } \\
\text { some no. }\end{array}$} & \multirow[t]{2}{*}{$\begin{array}{l}\text { Refer- } \\
\text { ences }\end{array}$} \\
\hline & & 1 & 2 & 3 & 4 & 5 & 6 & 7 & \\
\hline $0.5 \mathrm{M} \mathrm{NaCl}$ & $\begin{array}{l}\mathrm{A} \\
\mathrm{B} \\
\mathrm{D} \\
\mathbf{H} \\
\mathbf{R}\end{array}$ & $\mathbf{I}$ & $\begin{array}{l}5 ? \\
1\end{array}$ & $\begin{array}{l}2 \\
1 \\
1\end{array}$ & $\begin{array}{l}2 \\
1 \\
3 \\
4\end{array}$ & $l$ & $\begin{array}{l}1 \\
1 \\
1\end{array}$ & $\begin{array}{l}1 \\
3 \\
1\end{array}$ & 1 \\
\hline $\begin{array}{l}70 \% \text { ethanol } \\
(\mathrm{MW}<25,000)\end{array}$ & $\begin{array}{l}\text { A } \\
\mathbf{B} \\
\mathbf{D}\end{array}$ & & & $\begin{array}{l}2 \\
1\end{array}$ & $\begin{array}{l}2 \\
1\end{array}$ & 1 & 2 & $\begin{array}{l}1 \\
2\end{array}$ & 2,3 \\
\hline $\begin{array}{l}\mathrm{Cl}_{3} \mathrm{CH} / \mathrm{MeOH} \\
(2 / 1 ; \mathrm{v} / \mathrm{v})\end{array}$ & $\begin{array}{l}\text { A } \\
B \\
D \\
H\end{array}$ & & & & $\begin{array}{l}2 \\
1 \\
2\end{array}$ & & & $\begin{array}{l}1 \\
2 \\
2\end{array}$ & $2-4$ \\
\hline
\end{tabular}

" $T$. aestivum (genomes $\mathrm{ABD}$ ); H. vulgare $(\mathrm{H}) ; S$. cereale $(\mathrm{R})$. Chromosomes of the $\mathrm{H}$ genome have been numbered according to their homoeology with wheat chromosomes

- 1) Present report, 2) Aragoncillo et al. 1975, 3) RodriguezLoperena et al. 1975, 4) Garcia-Olmedo and Carbonero 1970, 5) Salcedo et al. 1984

to proteins 1,5 and 6 , was concomitant with the lack of expression of the genes encoding wheat components 2 and 4 from Fig. $1 \mathrm{~b}$.

Chromosomal locations of genes encoding albumins and globulins in rye were investigated in a similar manner as those in barley. About 20 main components were detected (Fig. 3a). Wheat-rye disomic addition lines were analysed by the same two-dimensional method and genes encoding 5 proteins were assigned to two chromosomes (Fig. 3b-d; Table 1). Two additional map components appeared in addition lines $\mathrm{IR}$ and $4 \mathrm{R}$ that could not be detected in either $T$, aestivum cv. 'Chinese Spring' or in $S$. cereale cv. 'Imperial' or in mixtures of the two samples.

\section{Discussion}

The salt extracts of wheat, barley and rye, which represent $15-25 \%$ of the total endosperm protein, consist of 20-25 individual components, as shown by the electrophoretic procedure used in the present study. From these data, it may be concluded that, on the average, each of these proteins represents about $0.5-1.0 \%$ of the total protein. This indirect estimate has been confirmed for some proteins by a more direct densitometric procedure using the purified proteins as standards (unpublished). This means that many albumins and globulins are as abundant in the endosperm as many individual components of the typical reserve prolamins $(50-60 \%$ of the total endosperm protein; up to 50 components in wheat). These data and the fact that the salt-soluble proteins are also used, together with the prolamins, as substrates by the germinating embryos, tend to obscure the traditional assumption of an exclusively non-storage function for albumins and globulins.

Based on the chromosomal locations of their genes and on their positions in the two-dimensional maps, 9 out of the 14 salt-soluble wheat proteins unambigutously assigned in the present work are identical with components of the $70 \%$ ethanol extract (Table 1) previously reported by Aragoncillo et al. (1975). Components 18 (chromosome 1B), 19 (chromosome 5B), 8 (chromosome 6B) and 13 and 14 (chromosome 7D) correspond to new assignments. The observations concerning components $1-5$, which are not included in the $70 \%$ ethanol extracts, could be explained by the existence of duplicate sets of genes for these proteins, respectively located in chromosomes $2 \mathrm{~A}$ and $2 \mathrm{~B}$ or, alternatively, by some sort of regulatory or modifier effect.

In this context, it should be pointed out that several laboratories have reported effects of this type on certain wheat prolamins by group 2 chromosomes (Shepherd 1968; Waines 1973; Brown and Flavell 198I). About one fourth of the components of the wheat two-dimensional map did not show variation among the aneuploid strains investigated and therefore no indication about the chromosomal locations of the corresponding genes could be obtained. This could be due either to the location of these genes in the unexplored part of the genome (chromosome $2 \mathrm{~A} ; \alpha$ arm of chromosome $4 \mathrm{~A}$; or cytoplasmic genomes) or to the existence of triplicate homoeologous genes encoding each of these map components.

Four of the six components assigned in barley correspond to previously reported components of the chloroform: methanol extract (Salcedo et al. 1984). Component 1 (chromosome $4 \mathrm{H}$ ) and 3 (chromosome $6 \mathrm{H}$ ) had not been previously assigned. Components 2 , 4,5 and 6 are identical with proteins CMa-1, CMe-1, CMb-l and CMd-1, respectively (Salcedo et al. 1984). However, we fail to detect, under the present analytical conditions, component CMc-1 encoded by chromosome $1 \mathrm{H}$ (equivalent to wheat homoeology group 7) in spite of the fact that it is at least partially salt-soluble (Salcedo et al. 1982, 1984). To our knowledge, no genes encoding salt-soluble proteins had been previously located in rye. A greater proportion of genes encoding albumins and globulins from barley and rye have remained unassigned because of the overlap of the proteins of these species with those of wheat in the addition lines. The lack of expression of some wheat genes in one barley addition line $(4 \mathrm{H}$ disomic addition) and, in the case of wheat-rye addition lines, the appearance of components that were not detected in the cultivars from which the lines were derived (1R 
and $4 \mathrm{R}$ disomic additions), seem to indicate that both negative and positive genetic interactions can take place between the added chromosomes and those of the recipient species. However, heterogeneity in the initial parental material can not be excluded.

Most of the salt-soluble proteins encoded by genes located in chromosomes of groups 4 and 7 in wheat and chromosomes 4 and $I$ of barley are soluble in chloroform: methanol mixtures and have been designated CM-proteins (Aragoncillo et al. 1975; Salcedo et al. 1984). We have presented biochemical and immunochemical evidence of sequence homology among CM-proteins encoded by genes located in both groups of chromosomes in the two species (Salcedo et al. 1982; Paz-Ares et al. 1983). In the case of rye, we have only preliminary evidence that at least two of the proteins assigned to chromosome 4 are CM-proteins, and have not yet been able to ascertain whether or not there are also genes for salt-soluble proteins in chromosome 7. An answer to this question could contribute to further clarify the proposed relationship of chromosome $4 R$ of $S$. cereale with homoeologous groups 4 and 7 of wheat (Koller and Zeller 1976). The possibility that at least some of the proteins encoded by genes located in chromosomes of group 3 might be structurally related to the CM-proteins has been recently raised (Salcedo et al. 1984, and unpublished results) and is being actively investigated. This would imply that at least some of the main components of the salt-soluble protein fraction are members of a widespread multigene family.

Acknowledgements. We acknowledge the gift of samples by E. R. Sears and K. W. Shepherd, the technical assistance of J. Garcia-Guijarro and a research grant from the Comision Asesora de Investigación Cientifica y Técnica.

\section{References}

Aragoncillo C, Rodriguez-Loperena MA, Carbonero P, Garcia-Olmedo $F$ (1975) Chromosomal control of non-gliadin proteins from the $70 \%$ ethanol extract of wheat endosperm. Theor Appl Genet 45:322-326

Brown JWS, Flavell RB (1981) Fractionation of wheat gliadin and glutenin subunits by two-dimensional electrophoresis and the role of group 6 and group 2 chromosomes in gliadin synthesis. Theor Appl Genet 59:349-359
García-Olmedo F, Carbonero P (1970) Homoeologous protein synthesis controlled by homoeologous chromosomes in wheat. Phytochemistry 9:1495-1497

Garcia-Olmedo F, Carbonero P, Jones BL (1982) Chromosomal locations of genes that control wheat endosperm proteins. In: Adv Cereal Sci Technol, AACC, Si Paul Minn, USA, pp 1-47

Islam AKMR. Shepherd KW, Sparrow DHB (1975) Addition of individual barley chromosomes to wheat. In: Gaul $\mathbf{H}$ (ed) Proc 3rd Int Barley Genet Symp, Garching. Thiemig, München, pp 260-270

Islam AKMR, Shepherd KW, Sparrow DHB (1978) Production and characterization of wheat-barley addition lines. In: Ramanujan S (ed) Proc 5th Int Wheat Genet Symp, New Delhi. Indian Soc Genet Plant Breed, Ind Agr Res Inst, New Delhi, pp 365-371

Koller OL, Zeller FJ (1976) The homoeologous relationships of rye chromosomes $4 R$ and $7 R$ with wheat chromosomes. Genet Res 28:177-188

Morris R, Schmidt JW, Mattern PJ, Johnson VA (1966) Chromosomal location of genes for flour quality in the wheat variety 'Cheyenne' using substitution lines. Crop Sci $6: 119-122$

Paz-Ares J, Hernandez-Lucas C, Salcedo G, Aragoncillo C, Ponz F, Garcia-Olmedo F (1983) The CM-proteins from cereal endosperm: immunochemical relationships. J Exp Bot 34:388-395

Riley R, Chapman V (1958) The production and phenotypes of wheat-rye chromosome addition lines. Heredity 12: $301-315$

Rodriguez-Loperena MA, Aragoncillo C, Carbonero P, García-Olmedo $F$ (1975) Heterogeneity of wheat endosperm proteolipids (CM proteins). Phytochemistry 14:1219-1223

Salcedo G, Fra-Mon P, Molina-Cano JL, Aragoncillo C, García-Otmedo F (1984) Genetics of CM-proteins (Ahordeins) in barley. Theor Appl Genet 68:53-59

Salcedo G, Sanchez-Monge R, Aragoncillo C (1982) The isolation and characterization of low molecular weight hydrophobic salt soluble proteins from barley. J Exp Bot 33: 1325-1331

Sears ER (1954) The aneuploids of common wheat. Mo Agric Exp Stn, Bull 572:1-58

Sears ER (1966) Chromosome mapping with the aid of telocentrics. In: Mackey J (ed) Proc 2nd Int Wheat Genet Symp, Lund. Heredity (Suppl) 2, pp 370 -381

Shepherd KW ([968) Chromosomal control of endosperm proteins in wheat and rye. In: Finlay $\mathrm{KW}$, Shepherd KW (eds) Proc 3rd Int Wheat Genet Symp, Canberra. Aust Acad Sci, pp 86-96

Waines JG (1973) Chromosomal location of genes controlling endosperm protein production in Triticum aestivum cv. 'Chinese Spring'. In: Sears ER, Sears LMS (eds) Proc 4th Int Wheat Genet Symp, Columbia. Mo Agric Exp Sin, University of Missouri, Columbia, pp 873-877 